\title{
PRESERVING OUR NATIONAL HERITAGE
}

\section{By PHILLIP D. JORDAN*}

Twice within twelve months, The New York Times, the most distinguished newspaper published in the United States, has charged that American students are ignorant of the story of their own history and their own national heritage. ${ }^{1}$ The Times, apparently suspecting that educational institutions in the United States had gradually swung away from the thesis that United States history was important for American citizens, conducted two surveys which were directed by Benjamin Fine, educational editor of the Times.

Although the results of these surveys were challenged, they seemed to confirm what many historians had suspected for years. During the past quarter century it was not uncommon to hear on many lips the phrase that "history was on the way out," that "United States history was not practical," and that what was needed were more courses of a "utilitarian" nature. Such courses of instruction would deal with contemporary problems, such as present-dey standards of living, poverty, crime, current political trends, and analyses of today's economic difficulties. The orientation course and the course which attempted to "integrate" or to "fuse" all phases of knowledge-sociology, government, economics, history, literature, geography, and even religion and philosophy-were conceived as substitutes for a knowledge of the basic development and maturity of the American way and of American ideals. The Times survey seemed to confirm and make real the impression that courses in the history of the United States were none too popular either with students or with educators.

The-Times, believing that its survey statistics were

*Phillip D. Jordan is associate professor of history at Miami University, Oxford, Ohio, editor of Teacher's Section of the Mississippi Valley Historical Review; born at Burlington, Iowa; graduated from Bur'ington high school, Northwestern University and received his master's degree from the University of lowa.

1The New York Times, June 21, 1942; April 4, 1943. See also Philip D. Jordan's "The New York Times Survey of United States History" in The Mississippi Valley Historical Review. September. 1942 and his "Is American History on the Way Out?" in The Chronicles of Oklahoma, March, 1943. 
correct and that its interpretations were justified, said that:

College freshmen throughout the nation reveal a striking ignorance of even the most elementary aspects of United States history, and know almost nothing about many important phases of this country's growth and development.

Last June [1942] a survey conducted by the New York Times revealed that 82 per cent of the colleges of this country do not require the teaching of United States history for the undergraduate degree.

One of the conclusions from the present study is that the students are in need of United States history on the college or university level, even though they have taken courses in this field in high school.

More impressive than the lack of knowledge is the amount of misinformation that the survey disclosed.

A large majority of the college freshmen showed that they had virtually no knowledge of elementary aspects of American history. They could not identify such names as Abraham Lincoln, Thomas Jefferson, Andrew Jackson, or Theodore Roosevelt, and they! had little conception of the significant trends that have made the United States the Nation it is today. ${ }^{2}$

The surveys brought to light other illuminating data: many more freshmen were taking courses in history other than that of the United States; more public colleges and universities demand United States history as a prerequisite for entrance than private or denominational colleges; by and large United States history is not required for the undergraduate or graduate degree in "any of the colleges or universities with the possible exception of the teachers colleges where nearly one-half did make it compulsory"; liberal arts colleges and universities "which account for most of the undergraduate students in the United States, are more opposed to the compulsory teaching of United States history than any of the other educational groups"; it "would seem . . . that in a little more than half the teacher training centers of this country men and women can be licensed for 2The New York Times, April 4, 1943 ; see also Congressional Record, Apria 6,
$1943,2998-3009 ;$ "Survey of United States Hittory in Colleges and Schools," Sen. Doc. 26, 78 cong., 1st sess., Washington, D. C., 1943. 
teaching positions without having had any course in United States history, either on the secondary or collegiate level"; United States history, in most institutions, is not a required subject for students majoring in economics or sociology; students majoring in government, for the most part, found that they were obliged to take courses dealing with the history of the United States; and some college presidents or administrators were in favor of making United States history courses compulsory.

\section{Storms of CRITICISM Follow Findings}

Findings such as they, as might be expected, brought waves of approval and storms of criticism. The $\mathrm{Na}$ tional Education Association, the past president of the National Association of Manufacturers, men in public office, and educators approved the spirit of the surveys," The Saturday Review of Literature remarked, as did many other Americans, that "It would be a pity if our colleges lagged behind in furnishing through courses in history the most essential basis for successful building of the future-a knowledge of the past." 4 Journalists, such as Dorothy Thompson and William McDermott, expressed themselves in favor of adequate instruction in history," and competent authors and historians, such as Bernard De Voto, supported the findings of the Times surveys. ${ }^{6}$ The matter was debated on the floor of the Senate of the United States. ${ }^{7}$

Not all sentiment, however, throughout the nation approved either the method or the results of the two Times surveys. Erling M. Hunt, editor of Social Education, thought the history test given by the Times to about 7,000 students was "weak in its exclusive attention to memory." 8 Other individuals charged that the

3The New York Times, June 28, 30; July 3; Sept. 13; 1942.

${ }^{4}$ The Saturday Review of Literature, Sept. 5, 1942, 10.

"Cincinnati Enquirer, April 9, 14 ; May 10, 1943; Cleveland Plain-Dealer, April 10,1943 .

"Bernard De Voto, “The Easy Chair," Harper's Magazine, July, 1943.

${ }^{7}$ Congressional Record, April 6, 10, 1943.

${ }^{8}$ The New York Times, April 6, 1943. 
test was weak mechanically, that students did not answer test questions seriously, that the findings did not represent the true condition in schools, and that the Times survey was "one of the biggest hoaxes in American history." Soon some significant literature was appearing which argued the controversy pro and con. ${ }^{10}$

By this time the issue had been joined and both sides were engaged in heated controversy. ${ }^{11}$ Not for a quarter of a century had the history of the United States received so much attention. Even the conservative historical associations of the nation began to take an active interest. On April 24, 1943, the Mississippi Valley Historical Association meeting in Cedar Rapids, Iowa, passed a resolution which called for the appointment of a committee "to study the current controversy concerning the teaching of American history and prepare a report consisting of a description and analysis of the situation, a statement of principles, and such specific recommendations as seem warranted."12

\section{Survey Committee Starts Task}

Within a month this program was underway and it was announced that the American Historical Association, the Mississippi Valley Historical Association, and the National Council for the Social Studies had been granted the sum of $\$ 10,000$ from the Rockefeller Foundation for a comprehensive survey of the history and social studies program in American schools and colleges. A committee of historians and educators headed by Dr. Edgar B. Wesley of the University of Minnesota was appointed for this task. ${ }^{13}$

It must not be thought, however, that the safety of

\footnotetext{
${ }^{\theta}$ The New York Times, April 8, 1943.

10Allan Nevins, "American History for Americans," New York Times Magazine, May 3, 1942, and "More American History; A Letter, "Social Education, December, 1942 ; Erling Hunt, "More American History," ibid., October, 1942 and "American History in Democratic Education," ibid., December, 1942 ; Chares A. Beard, "A Cha'lenge to Educational Leaders," The Civic Leader, September 28, 19.12; Edgar B. Wesley, "History in the School Curriculum," Mississippi Valley Historical Review, March, 1943.

${ }^{11}$ The New York Times, April 11, 12, 13, 18, 19, 20, 1943.

${ }^{12}$ The New York Times, April 25, 1943.

13The New York Times, June 23, 1943.
} 
the national heritage may be preserved only by the press, research foundations, teachers, and historical associations. "Mr. and Mrs. America" also have a responsibility if history is not to be tossed into the discard. Their obligation is to interest themselves in history and to stimulate their children to an appreciation of the national heritage. They must also urge the younger generation to register for courses in the narrative of their nation in the grade school, the secondary school, and in the college and university. The democratic process cannot be fully understood without reference to the historical pattern. ${ }^{14}$ And "Mr. and Mrs. America" must assume the responsibility of impressing upon local school administrators and teachers the significance and functional value of American history. Frequently the Parent-Teachers Association may serve as a vehicle to carry this lesson to both administrator and classroom instructor. The public interest makes emphasis upon history mandatory. ${ }^{15}$

There are other ways by which a knowledge of the American past may be brought to students and to the public. State historical societies can be of great assistance by disseminating knowledge of local history in their journals, by supplying village, county, city, and state newspapers with feature stories dealing with local background and prominent figures who played a major role in the political, social, and cultural activities of the state, by sponsoring essay contests among lower grade and high school pupils, and by furnishing speakers to luncheon clubs and other organizations. Not the least of the significant contributions of the state historical societies are the library and reference rooms where citizens may be guided with sympathetic encouragement in their personal research problems.

\footnotetext{
1+Educational Policies Commission, The Purposes of Education in American Democracy (Washington, D. C. 1938), chap. 2.

15Educational Policies Commission, The Unique Funetion of Education in Amer. ican Democracy (Washington, D. C., 1937), 5 .
} 


\section{Professional Historians to Renew Faith}

Whatever may be the long-time results of the two surveys undertaken by The New York Times, one thing must be said: the Times has performed an invaluable public and patriotic service in exposing the place of United States history in American education and in compelling professional historians to evaluate not only the content, but also the importance, of their own subject. It seems fairly certain that the people of the nation want their children to know the story of their own land. Historians who have been timid and who have felt that United States history "is on the way out" should renew their own faith in their subject and work toward making American history more and more available to the younger generation.

Formal training in United States history, of course, does not necessarily guarantee love of country and competent citizenship. Many Americans who have never been "trained" in the history of the nation perform their duties in local communities and at the polls with honesty and vigor. And many more citizens who have had only grade and secondary instruction in the narrative of their country function admirably. In short, required courses in any subject, although they may aid in determining attitudes, cannot guarantee individual proficiency. Even the Times pointed out editorially that it would be "unrealistic to believe that a course in American history can work miracles." On the other hand, it is difficult to see how courses in United States history could do harm. President Roosevelt put the issue squarely when he said: ". . . a nation must believe in three things. It must believe in the past. It must believe in the future. It must, above all, believe in the capacity of its people to learn from the past that they can gain in judgment for the creation of the future." 
Copyright of Annals of Iowa is the property of State of Iowa, by \& through the State Historical Society of Iowa and its content may not be copied or emailed to multiple sites or posted to a listserv without the copyright holder's express written permission. However, users may print, download, or email articles for individual use. 